\title{
PHYTOCHEMISTRY AND LARVICIDAL ACTIVITY OF Spermacoce latifolia AUBL. (Rubiaceae) IN THE CONTROL OF Aedes aegypti L. (Culicidae)
}

\author{
FITOQUÍMICA E ATIVIDADE LARVICIDA DE Spermacoce latifolia AUBL. \\ (Rubiaceae) NO CONTROLE DE Aedes aegypti L. (Culicidae)
}

\section{Ana Claudia Oliveira Firak COSMOSKI ${ }^{1}$; Antonia Railda ROEL ${ }^{1}$; Karla Rejane de Andrade PORTO' ${ }^{\text {; Rosemary MATIAS }}{ }^{2}$; Michel Robin HONER ${ }^{1}$; Priscila Rezende MOTTI ${ }^{1}$}

1. Pos Graduate Program in Biotechnology, Catholic University Dom Bosco, Campo Grande, MS, Brazil. anaclaudiafirak@gmail.com; 2. Pos Graduate Program in Environment and Regional Development, University Anhanguera -UNIDERP, Campo Grande, MS, Brazil.

\begin{abstract}
In the search for alternative ways to control Aedes aegypti with minimal environmental impact and in a manner that preserves human health, this study sought to evaluate the larvicidal effect of the invasive and antioxidant Spermacoce latifolia plant by performing a phytochemical study. Phytochemical screenings were done according to characterization reactions and thin layer chromatography. Phenolics compounds content (Folin-Ciocalteu's) and flavonoids $\left(\mathrm{AlCl}_{3}\right)$ spectrophotometric was performed, and the antioxidant activity was determined by the 2,2diphenyl-1-picrylhydrazyl (DPPH). The phytochemical results revealed the presence of phenolic, flavonoid, tannin, steroid, free triterpene, coumarin, and alkaloid compounds. The content of total phenols (TPs) $\left(482.7 \pm 1.8 \mathrm{mg} \mathrm{mgGA} \mathrm{g}^{-1}\right)$ and flavonoids $\left(165.4 \pm 1.5 \mathrm{mg} \mathrm{QE} \mathrm{g}^{-1}\right)$ accounted for the antioxidant activity of $150 \mu \mathrm{g} \mathrm{mL}^{-1}$ methanolic extract. In the proposed bioassays, groups of 25 third-stage larvae were challenged at different concentrations of plant crude extract (1.0, $0.5,0.25$, and $0.1 \mathrm{mg} \mathrm{mL}^{-1}$ ) of weight per volume in four replicates. In multiple concentration tests, the concentrations were selected to range from $0 \%$ to $100 \%$ mortality after 24 hours of contact with the solution. Toxicity was defined as the

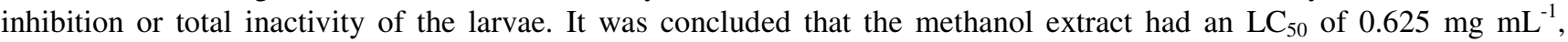
indicating its potential use as a larvicide against $A$. aegypti and linking its activity to its phenolic and flavonoid components.
\end{abstract}

KEYWORDS: Vector control. Plant active ingredients. Plant insecticides.

\section{INTRODUCTION}

Dengue is a viral infection transmitted by mosquitoes of the genus Aedes and is typical of tropical and subtropical regions. The incidence of dengue has increased due to variations in climate and rainfall. Currently, this disease affects 50 to 100 million people in over 100 countries worldwide and about two-fifths of the global population at risk of being infected by dengue virus (GARCEZ et al., 2013).

However, current measures to control dengue epidemics, such as the use of organophosphates and carbamates have not been effective due to vector resistance and plasticity that reappears under different guises during each epidemic cycle, triggering serious public health problems (TEIXEIRA et al., 2009).

The need to seek control methods with minor action toxic to humans and the environment has stimulated the search for new ways to combat $A$. aegypti, and the plants are cited as one of the effective alternatives because they are rich in bioactive ingredients. So, the high Brazilian plant diversity emerges as one way to control dengue. Their natural products are in promising vector control sources, because in addition to being rapidly degradable, renewable resources easily accessible, yet have low production cost (ROEL, 2001).

And within that botanical diversity, are the Rubiaceae, that are among the most numerous families of plants, and are noted for being bioproducer of a large number of phytochemicals such as iridoids, terpenoids, flavonoids, tannins, quinones and alkaloids. Species of the Spermacoce genus have an impressive number of chemical constituents, with medicinal properties such as antiinflammatory, antimicrobial, antioxidant, antitumor, anti-ulcer and larvicidal, supporting their relevance to this study (COSTA et al., 2006).

Considering the above-mentioned aspects, this work aimed to evaluate the classes of secondary metabolites of an $S$. latifolia methanolic extract, determining larvicidal activity against $A$. aegypti larvae, and their utility as a botanical alternative to chemical agents.

\section{MATERIAL AND METHODS}

\section{Plant sample collection and identification}

Plant samples were collected at the Três

Barras Farm School, Campo Grande, State of Mato 
Grosso do Sul - MS (20³3'37.44043” S, 54'32'10.3824" W), in 2008. The samples were dehydrated, and a voucher specimen was added to the Herbarium of the University Anhanguera Uniderp under file number 1543 after botanical identification by Professor Eloty Justina Dias Schleder.

\section{Preparation of the methanol extract}

The aerial parts of the plant were cleaned, dried in an air ventilated oven at $45{ }^{\circ} \mathrm{C}$ (Model MA35, MARCON) for 4 days, weighed, pulverised in an electric grinder (Model MA048, MARCONI), and sieved (mesh No. 60). Five hundred and eighty grams of processed material was extracted with methanol (99.5\%) in an ultrasonic bath for 60 minutes (Model 1450, UNIQUE), followed by room-temperature maceration; this procedure was repeated daily for 15 days. The solvent was evaporated under vacuum on a rotary evaporator (Model MA120, Tecnal) to yield 25.0 g of crude methanolic extract.

\section{Phytochemical analysis}

Phytochemicals were determined by humidification (crude extract - 20\%), as per colorimetric testing and/or chemical precipitation methods described in Matos (2009). The analyses were performed in three replicates, and the results were compared with the methanolic extract (COSTA, 2002). Confirmation of the class of secondary metabolites and their elution system were performed by thin layer chromatography (TLC: silica gel $60 \mathrm{~F}_{254}$ ) using specific reagents for terpenes, alkaloids, coumarins, flavonoids, and phenolic compounds (WAGNER; BLADT, 2009).

The methanolic extract were used to quantify the flavonoids and total phenolis. The flavonoids were determined based on method of Peixoto Sobrinho et al. (2008). The total phenolic (FT) compounds were determined based on the Folin-Ciocalteu method, as per method of Sousa et al. (2007).

\section{Antioxidant activity}

The antioxidant potential was determined based on the free radical scavenging activity of 2,2diphenyl-1-picryl-hydrazyl (DPPH). The $20 \%$ methanolic extract $\left(20 \mathrm{~g} 100 \mathrm{~mL}^{-1}\right)$ was diluted at concentrations of $250,200,150,100,50$, and $25 \mu \mathrm{g}$ $\mathrm{mL}^{-1}$, and $2 \mathrm{~mL}$ of DPPH in methanol was added (24 mg DPPH/100 mL of methanol). After 30 minutes, the absorbance was measured in a spectrophotometer at $515 \mathrm{~nm}$. DPPH in methanol solution was used as a negative control, and BHT (butylated hydroxytoluene, at the same concentrations used in the samples) was employed as a positive control (THAIPONG et al., 2006). The percentage of antioxidant activity ( $\%$ AA) was calculated using the formula: $\left.\% A A=\left(A_{0}-A_{s}\right) / A_{0}\right)$ $\mathrm{x} 100$, where $\mathrm{A}_{0}$ is the absorbance of $\mathrm{DPPH}$ (control) and $A_{s}$ is the absorbance of the sample in the presence of DPPH (SOUSA et al., 2007).

\section{Bioassay}

A. aegypti eggs were collected in the city of Campo Grande with the aid of an official from CCZ (Centre for Zoonoses Control) of Campo Grande MS. Bioassays were performed at the Laboratory of Entomology of Dom Bosco Catholic University.

The eggs were allowed to mature for 1 week and then were subjected to hatching in running water ( $\mathrm{pH} 6-7)$. The larvae obtained from the breeding stock were separated by age for the toxicity tests. A biochemical oxygen demand (BOD) incubator was used (adjusted to $27 \pm 2{ }^{\circ} \mathrm{C}$ ), and the mosquitoes were subjected to 14 hours of photoperiod exposure during their egg and larvae stages. In the adult stage, the females were fed pigeon-blood meals three times per week, and the males were fed sweetened water.

Twenty-five third-stage larvae were used for every $25 \mathrm{~mL}$ solution of $S$. latifolia methanol extract, at concentrations of 1.0, 0.5, 0.25, and 0.1 $\mathrm{mg} \mathrm{mL} \mathrm{m}^{-1}$, tested in quadruplicate for 24 hours. A negative control (blank solution) and positive control (rotenone) were tested simultaneously (CONSOLI et al., 1989).

The probit analysis method was used via the POLO-PC software program to obtain the lethal concentration $50\left(\mathrm{LC}_{50}\right)$ and lethal concentration (LC) values with their respective confidence intervals.

\section{RESULTS AND DISCUSSION}

Characterized by the classification of the family as a plant insecticide, and in agreement to the results of phytochemical analysis, Table 1 shows that the methanol extract of aerial parts of $S$. latifolia was effective in controlling larvicide to be tested in four concentrations: $1.0,0.5,0.25$, and 0.1 $\mathrm{mg} \mathrm{mL}^{-1}$. The $\mathrm{LC}_{50}$ was in the range of $0.61-0.63$ $\mathrm{mg} \mathrm{mL}{ }^{-1}\left(\mathrm{LC}_{50}=0.625 \mathrm{mg} \mathrm{mL}^{-1}\right)$. The minimum concentration capable of causing mortality $\left(\mathrm{LC}_{10}\right)$ was $0.125 \mathrm{mg} \mathrm{mL}$, and the maximum toxicity ( $\mathrm{LC}_{90}$ ) was $1.125 \mathrm{mg} \mathrm{mL}^{-1}$ after a 24-hour exposure (Figure 1). By observing the heterogeneity of the results and the range of 0.95 correlation, it is possible to observe a limit of variation between 
dosages of 7.309 and the average of the responses to \pm 2.619 are single.

Table 1. Larvicidal activity of Spermacoce latifolia (Rubiaceae) methanolic extracts against Aedes aegypti L. (Culicidae) third-stage larvae.

\begin{tabular}{cccc}
$\begin{array}{c}\text { Lethal Concentration } \\
\text { (LC); } \\
\text { Measurement }\end{array}$ & $\mathrm{LC}_{10} 0.125 \mathrm{mg} \mathrm{mL}^{-1}$ & $\mathrm{LC}_{50} 0.62 \mathrm{mg} \mathrm{mL}^{-1}$ & $\mathrm{LC}_{90} 1.25 \mathrm{mg} \mathrm{mL}^{-1}$ \\
\cline { 2 - 4 } & $0.118-0.13 \mathrm{mg} \mathrm{mL}^{-1}$ & $0.61-0.63 \mathrm{mg} \mathrm{mL}^{-1}$ & $\begin{array}{c}1.117-1.13 \mathrm{mg} \mathrm{mL}_{1}^{-} \\
\end{array}$
\end{tabular}

The dispersion of data over time reveals an increasing linear regression, with $\mathrm{R}^{2}$ value of 0.93 (Figure 1), approaching effectively the positive control rotenone which certified $100 \%$ mortality and no deaths were observed in the negative control without product

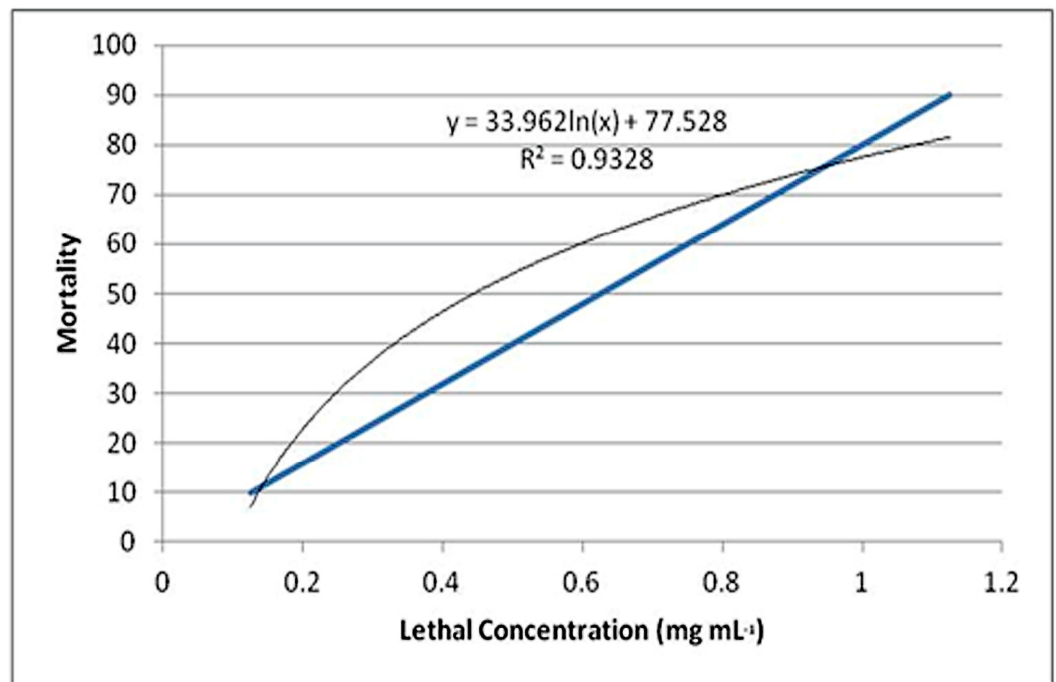

Figure 1. Toxic effect of different concentrations $\left(\mathrm{mg} \mathrm{mL}^{-1}\right)$ Spermacoce latifolia of on larvae of Aedes aegypti of treatment.

The best concentration or concentrations that caused mortality above $30 \%$, as described in the literature (MCLAULING, 1991), were used to adjust the concentrations for the bioassay in this study. The $\mathrm{LC}_{50}$ was determined to be $0.62 \mathrm{mg} \mathrm{mL}^{-1}$ (Table 1, Figure 1). This result showed promise for larvicidal activity, in addition to the chemical analysis that revealed the presence of phytochemicals with similar activity responses to other Rubiaceae species.

In this study, the phytochemical analysis of the methanolic extract of $S$. latifolia aerial parts revealed the presence of phenolic compounds (482.7 $\pm 1.8 \mathrm{mg}$ GAE g), flavonoids $(165.4 \pm 1.5 \mathrm{mg} \mathrm{QE}$ $\mathrm{g}$ ), tannins, steroids, free triterpenes, coumarins and alkaloids. The \% AA results from the S. latifolia methanol extract confirmed the presence of phenols and flavonoids, and the concentration that showed the highest oxidation potential was $150 \mu \mathrm{g} \mathrm{mL}^{-1}$.

There are no reports regarding the total phenolis and total flavonoid content in Spermacoce species. The Rubiaceae family is known for the production of alkaloids, iridoids, and anthraquinones (YOUNG et al., 1996), and flavonoids have been isolated from species of this family (LOPES et al., 2004, CARDOSO et al., 2005; PINTO et al., 2008).

Noiarsa et al. (2006) identified 18 substances from the aerial parts of Spermacoce laevis Roxb. including flavonoids and iridoids, the latter being designated as a chemotaxonomic marker for species of the Rubeaceae family. The antioxidant activity of $S$. articularis was attributed to the presence of steroids and triterpenoids in the aerial parts of this species (SAHA et al., 2004) and Kaviarasan et al. (2008) determined the antioxidant activity of $S$. hispida and isolated flavonoids.

Nazar et al. (2009) and Dhanasekaran et al. (2013) investigated the larvicidal, ovicidal, and repellent potential of an S. hispida crude ethanol extract against Anopheles stephensi, A. aegypti, and Culex tritaeniorhynchus. A pronounced lethal activity $\left(\mathrm{LC}_{50}=89.45 \mathrm{mg} \mathrm{L}^{-1}\right)$ was recorded against Anopheles stephensi. S. hispida exhibited an 
Phytochemistry and larvicidal...

ovicidal activity higher than $50 \%$ against the mosquito eggs (at $100 \mathrm{mg} \mathrm{L}^{-1}$ ). At a $200 \mathrm{mg} \mathrm{L}^{-}$ ${ }^{1}$ concentration, the ethanol extract exhibited $100 \%$ ovicidal activity against the insects tested. The extract provides $100 \%$ repellence protection against adult female mosquitoes, at up to 120 minutes of exposure.

The ethanol extract of $S$. verticillata, collected in northeastern Brazil, was effective at a $250 \mathrm{mg} \mathrm{L}^{-1}$ concentration, with a mortality rate above $75 \%$ against the fourth-stage larvae of $A$. aegypti. Iridoids were identified in this species (SOUZA et al., 2013).

In the present study, the presence of phenolic compounds, and within this group, the flavonoids, detected in the methanolic extract are indicative of insecticidal activity. Kotkar et al. (2002) considered the phenolic compounds to be phytochemicals with insecticidal activity, based on the action of their hydroxyl groups against the larval enzyme systems (VALENCIA, 1995), which are enzyme systems similar to those involved in the respiratory chain, causing potent inhibition (BOBADILLA, 2005).

Flavonoids isolated from the leaves of Polygonum senegalese Meissn exhibited insecticidal and $A$. aegypti larvae growth inhibitory activity, even at low concentrations (GIKONYO et al., 1998; GARCEZ et al., 2009). The species that showed strong larvicidal activity against $A$. aegypti, with $\mathrm{LC}_{50}$ values between 80 and $470 \mathrm{~g} \mathrm{~L}^{-1}$, belonged to the Rubiaceae family, and this activity has been related to bioactive flavonoids. It is also established that the rotenoids that belong to the isoflavones class have strong activity against $A$. aegypti larvae.

Pohlit et al. (2004) evaluated the aqueous, ethanol, and methanol extracts of various native plant species found in the Amazon region, among them, seven species of the Piper genus. However, only the lyophilised methanol extract of $P$. aduncum L. (leaf and root) and $P$. tuberculatum Jacq (leaf, fruit, and stem) were tested for activity against $A$. aegypti larvae; a single concentration of $0.5 \mathrm{~g} \mathrm{~L}^{-1}$ caused $100 \%$ mortality of the larvae.
COSMOSKI, A. C. O. F. et al.

In addition to studies of plant extracts, recent investigations have focused on the research and use of essential oils or isolated compounds that act against mosquitoes, including A. aegypti. Cavalcanti et al. (2004) evaluated the larvicidal activity of nine essential oils of plants found in northeastern Brazil. It was observed that oils of Ocimum americanum and Ocimun gratissimum (Lamiaceae) have better efficacy against $A$. aegypti, with $\mathrm{LC}_{50}$ values of $0.067 \mathrm{~g} \mathrm{~L}^{-1}$ and $0.060 \mathrm{~g} \mathrm{~L}^{-1}$, respectively.

An ethanol extract from Piper nigrum exhibited larvicidal action against $A$. aegypti at concentrations of $0.98 \mathrm{~g} \mathrm{~L}^{-1}$, as did the isolated fractions piperolein-A $\left(1.460 \mathrm{~g} \mathrm{~L}^{-1}\right)$ and piperine (1.530 $\left.\mathrm{g} \mathrm{L}^{-1}\right)$ (SIMAS et al., 2004). Abed et al. (2007) demonstrated the Copaifera reticulata oleoresin's larvicidal activity against $A$. aegypti at concentrations of $0.0089 \mathrm{~g} \mathrm{~L}^{-1}$ and $0.0594 \mathrm{~g} \mathrm{~L}^{-1}$ for the $\mathrm{LC}_{50}$ and $\mathrm{LC}_{90}$, respectively. Based on the $\mathrm{LC}_{50}$ $\left(0.625 \mathrm{mg} \mathrm{mL}^{-1}\right)$ obtained in this study from the methanol extract of $S$. latifolia aerial parts, this species exhibited bioinsecticidal activity against $A$. aegypti larvae, thus expanding the possibility for its use in controlling this vector.

\section{CONCLUSION}

The methanolic extract of $S$. latifolia aerial parts exhibits antioxidant activity, and this activity is linked to the presence of phenolic and flavonoid compounds, which are the predominant class of secondary metabolites. This extract has insecticidal activity for controlling A. aegypti larvae.

\section{ACKNOWLEDGEMENTS}

Pantanal Research Centre (CPP), National Institute of Science and Technology in the Wetlands (INAU), National Council for Scientific and Technological Development (CNPq /MCT), Foundation to Support the Development of Education, Science, and Technology of the state of Mato Grosso do Sul (FUNDECT).

RESUMO: Na busca de alternativas de controle do Aedes aegypti que minimizem os impactos ambientais e preserve a saúde humana, procurou-se neste trabalho avaliar o efeito larvicida da planta invasora Spermacoce latifolia e antioxidante e realizar estudo fitoquímico. As análises fitoquímicas foram realizadas por meio de reações de caracterização e cromatografia de camada delgada. O teor de compostos fenólico (Folin-Ciocalteu), flavonoides ( $\mathrm{AlCI}_{3}$ ) foram realizados utilizando a espectroscopia, e a atividade antioxidante foi determinada pelo método DPPH (2,2-difenil-1-picrilhidrazil). Os resultados fitoquímicos indicaram a presença de compostos fenólicos; flavonoides; taninos, esteroides e triterpenos livre, cumarinas e alcaloides. O conteúdo de fenóis totais $\left(482,7 \pm 1,8 \mathrm{mgGA} \mathrm{g}^{-1}\right)$ e flavonoides $\left(165,4 \pm 1,5 \mathrm{mg} \mathrm{QE} \mathrm{g}^{-1}\right)$ justificam a atividade antioxidante de $150 \mu \mathrm{g} \mathrm{mL}^{-1}$ do extrato metanólico. Nos bioensaios propostos usou grupos de 25 larvas de terceiro estádio, em diferentes concentrações das soluções dos extratos brutos $\left(1,0 ; 0,5 ; 0,25\right.$ e $\left.0,1 \mathrm{mg} \mathrm{mL} \mathrm{m}^{-1}\right)$ de peso por volume para quatro réplicas. Nos testes de concentrações múltiplas foram eleitas as concentrações que 
produziram mortalidade entre $0 \%$ e $100 \%$, após o período de 24 horas de contato com as soluções. Foi definida como

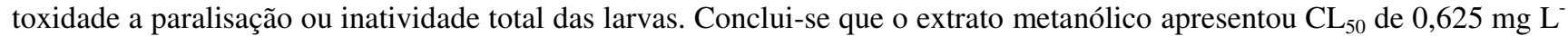

${ }^{1}$ e indica potencialidade larvicida para o A. aegypti e esta atividade pode estar ligada aos compostos fenólicos e flavonoides.

PALA VRAS-CHAVE: Controle de vetores. Princípios ativos vegetais. Plantas inseticidas.

\section{REFERÊNCIAS}

ABED, R. A.; CAVASIN, G. M.; SILVA, H. H. G.; GERIS, R. E.; SILVA, I. G. Alterações morfohistológicas em larvas de Aedes aegypti (Linnaeus, 1762) (Diptera, Culicidae) causadas pela atividade larvicida do óleoresina da planta medicinal Copaifera reticulata Ducke (Leguminosae). Revista de Patologia Tropical, Goiânia, v. 36, n. 1, p. 75-86, jan.- abr. 2007. http://dx.doi.org/10.5216/rpt.v36i1.1819

BOBADILLA, M.; ZAVALA, F.; SISNIEGAS, M.; ZAVALETA, G.; MOSTACERO, J.; TARAMONA, L. Evaluación larvicida de suspensiones acuosas de Annona muricata Linnaeus «guanábana» sobre Aedes aegypti Linnaeus (Diptera, Culicidae). Rev. Peru Biol., Lima, v. 12, n.1, p. 145-152, jun. 2005.

CAVALCANTI, E. S. B.; MORAIS, S. M.; LIMA, M. A. A.; SANTANA, E. W. P. Larvicidal Activity of essential oils from Brazilian plants against Aedes aegypti L. Mem. Inst. Oswaldo Cruz, Rio de Janeiro, v. 99, n. 5, p. 541-544, ago. 2004.

CARDOSO, C. L.; SILVA, D. H. S.; CASTRO-GAMBOA, I.; BOLZANI, V. S. New biflavonoid and other flavonoids from leaves of Chimarrhis turbinate and their antioxidant activities. J Braz Chem Soc, Campinas, v. 16, n. 6, p. 1353-1359, nov. - dez. 2005. http://dx.doi.org/10.1590/S0103-50532005000800008

COSTA, A. F. Farmacognosia. 5. ed. Lisboa: Calouste Gulbenkian. 2002. 1117p. v.2.

DHANASEKARAN, S.; KRISHNAPPA, K.; ANANDAN, A.; ELUMALAI, K. Larvicidal, ovicidal and repellent activity of selected indigenous medicinal plants against malarial vector Anopheles stephensi (Liston.), dengue vector Aedes aegypti (Linn.) and Japanese encephalitis vector, Culex tritaeniorynchus (Giles.) (Diptera: Culicidae). Journal of Agricultural Technology, Thailand, v. 9, n. 1, p. 29-47, jan. 2013.

GARCEZ, W. S.; GARCEZ, F. R.; SILVA, L. M. G. E.; SARMENTO, U. C. Substâncias de Origem Vegetal com Atividade Larvicida Contra Aedes aegypti. Revista Virtual de Química, Niteroi, v. 5, n. 3, p. 363- 393, mai. - jun. 2013.

GARCEZ, W. S.; GARCEZ, F. R.; SILVA, L. M. G. E.; HAMERSKI, L. Larvicidal activity against Aedes aegypti of some plants native to the West-Central region of Brazil. Bioresource Technology, England, v. 100, p. 6647-6650, dec. 2009. http://dx.doi.org/10.1016/j.biortech.2009.06.092

GIKONYO, N. K.; MWANGI, R. W.; MIDIWO, J. O. Toxicity and growth-inhibitory activity of Polygonum senegalense (Meissn.) surface exudate against Aedes aegypti larvae. International Journal of Tropical Insect Science, Cambridge, v. 18, n. 3, p. 229-234, dec. 1998. http://dx.doi.org/10.1017/S1742758400023456

KAVIARASAN, K.; KALAIARASI. P.; PUGALENDI. V. Antioxidant efficacy of flavonoid-rich fraction from Spermacoce hispida in hyperlipidemic rats. J. Appl. Biomed., Bohemia, v. 6, n. 1, p. 165-176, jan. 2008.

KOTKAR, H.; MENDKI, P.; SADAN, S.; JHA, S.; UPASANI, S.; MAHESHWARI, V. Antimicrobial and pesticidal activity of partially purified flavonoids of Annona squamosa. Pest Manag Sci., USA, v. 58, n. 1, p. 33-37, jan. 2002.

LOPES, M. N.; OLIVEIRA, A. C.; YOUNG, M. C. M.; BOLZAN, V. S. Flavonoids from Chiococca braquiata (Rubiaceae). J. Braz. Chem. Soc., Campinas, v. 15, n. 4, p. 468-471, jul. - ago. 2004. 
MCLAUGHLIN, J. L. Crown gall tumours on potato disc and brine shrimp lethality: two simple bioassays for higher plant screening and fractionation in methods in plant biochemistry. London: Ed. K. Hostettmann. 1991. p. 1-32.

MATOS, J. F. A Introdução a fitoquímica experimental. Fortaleza: UFC, 2009. 141p.

NAZAR, S. R.; WILLIAMS, G. P.; ALI, M. S.; SUGANTHI, P. Screening of Indian Coastal Plant Extracts for Larvicidal Activity of Culex Quinquefasciatus. Indian Journal of Science and Technology, India, v. 2, n. 3, p. 24-27, mar. 2009.

NOIARSA, P.; RUCHIRAWAT, S.; OTSUKA, H.; KANCHANAPOOM, T. A new iridoid glucoside from the Thai medicinal plant, Morinda elliptica Ridl. J Nat Med, Grã-Bretanha, v. 60, p. 322-324, oct. 2006.

PEIXOTO SOBRINHO, T. J. S.; SILVA, C. H. T. P.; NASCIMENTO, J. E.; MONTEIRO, J. M.; ALBUQUERQUE, U. P.; AMORIM, E. L. C. Validação de metodologia espectofotométrica para qualificação dos flavonóides de Bauhinia cheilantha (Bongard) Steudel. Rev. Bras. Cienc. Farm., São Paulo, v. 44, n. 4, p. 683-689, out. - dez. 2008.

PINTO, D. S.; TOMAZ, A. C. A.; TAVARES, J. F.; TENÓRIO-SOUZA, F. H.; DIAS, C. S.; BRAZ-FILHO, R.; CUNHA, E. V. L. Secondary metabolites isolated from Richardia brasiliensis Gomes (Rubiaceae). Rev. Bras. Farmacogn., Curitiba, v. 18, p. 3, p. 367-372, jul. - set., 2008.

POHLIT, A. M.; QUIGNARD, E. L. J.; NUNOMURA, S. M.; TADEI, W. P.; HIDALGO, A. F.; PINTO, A. C. S.; SANTOS, E. V. M.; MORAIS, S. K. R.; SARAIVA, R. C. G.; MING, L. C.; ALECRIM, A. M.; FERRAZ, A. B.; PEDROSO, A. C. S.; DINIZ, E. V.; FINNEY, E. K.; GOMES, E. O.; DIAS, H. B.; SOUZA, K. S.; OLIVEIRA, L. C. P.; DON, L. C.; QUEIROZ, M. M. A. Screening of plants found in the State of Amazonas, Brazil for larvicidal activity against Aedes aegypti larvae. Acta Amaz, Manaus, v. 34, n. 1, p. 97-105, jan. 2004. http://dx.doi.org/10.1590/S0044-59672004000100012

ROEL, A. R. Utilização de plantas com propriedades inseticidas: uma contribuição para o desenvolvimento rural sustentável. Interações, Campo Grande, v. 1, n. 2, p. 43-50, mar. 2001.

SAHA, K.; LAJIS, N. H.; ISRAF, D. A.; HAMZAHD, A. S.; KHOZIRAH, S.; KHAMISA, S.; SYAHIDA, A. Evaluation of antioxidant and nitric oxide inhibitory activities of selected Malaysian medicinal plants. J. Ethnopharmacol., Ireland, v. 92, p. 263-267, jun. 2004.

SIMAS, N. K.; LIMA, E. C.; ROCHA CONCEIÇÃO, S.; KUSTER, R. M.; OLIVEIRA FILHO, A. M. Produtos naturais para o controle da transmissão da dengue: atividade larvicida de Myroxylon balsamum (óleo vermelho) e de terpenóides e fenilpropanóides. Quím. Nova, São Paulo, v. 27, n. 1, p. 46-49, jan. - fev. 2004. http://dx.doi.org/10.1590/s0100-40422004000100009

SOUSA, C. M. M.; SILVA, H. R.; VIEIRA-JUNIOR, G. M.; AYRES, M. C. C.; COSTA, C. L. S.; ARAÚJO, D. S.; CAVALCANTE, L. C. D.; BARROS, E. D. S.; ARAÚJO, P. B. M.; BRANDÃO, M. S.; CHAVES, M. H. Fenóis totais e atividade antioxidante de cinco plantas medicinais. Quim Nova, São Paulo, v. 30, n. 1, p. 351-355, mar. - apr. 2007. http://dx.doi.org/10.1590/S0100-40422007000200021

SOUZA, R. K. D.; ALCANTARA, M. M. A. C.; PESSOA DA SILVA, M. A. Aspectos etnobotânicos, fitoquímicos e farmacológicos de espécies de Rubiaceae no Brasil. Rev Cubana Plant Med, Havana, v. 18, n. 1, p. 140-156, jan. - mar. 2013.

TEIXEIRA, M. G.; COSTA, M. C. N.; BARRETO, F.; BARRETO, M. L. Dengue: twenty-five years since reemergence in Brazil. Cad. Saúde Pública, Rio de Janeiro, v. 25, n. 1, p. 57-518, jan. 2009. 
THAIPONG, K.; BOONPRAKOB. U.; CROSBY. K.; CISNEROS-ZEVALLOS. L.; BYRNE. D. H. Comparison of ABTS, DPPH, FRAP and ORAC assays for estimating antioxidant activity from guava fruit extracts. J Food Comps Anal, New York, v. 19, p. 669-675, set. - nov. 2006.

http://dx.doi.org/10.1016/j.jfca.2006.01.003

VALENCIA, C. Fundamentos de fitoquímica. México: Edit. Trillas. 1995.

WAGNER, H.; BLADT, S. Plant drug analysis. 3.ed. New York: Springer Verlag. 2009.

YOUNG, M. C. M.; BRAGA, M. R.; DIETRICH, S. M. C.; BOLZANI, V. S.; TREVISAN, L. M. V.;

GOTTLIEB, O. R. Chemosystematic markers of Rubiaceae. Opera Bot Bel, USA, v. 7, p. 205-212, jan. 1996. 